\title{
Getting Involved in Society
}

\author{
Xiangmeng Huang
}

\section{Self-realization Through Work-Interview with $\mathbf{M r} . \mathrm{ZL}^{1}$}

ZL, male, born in 1982. The only child in the family. Grade IV intellectual disability. Graduated from a special education school. Now working at Shanghai Papa John's. Interviewee: $\mathrm{ZL}$

Interviewer and writer: Xiangmeng Huang

Interview dates: September 25 and October 16, 2016

Interview place: The restaurant where he works.

\section{Lisp not Taken Seriously, Optimal Treatment Time Missed}

Q: The purpose for today's talk is to know something about your daily life, chronologically from your childhood first. Just tell me what you remember. It doesn't matter if you can't remember, so take it easy.

ZL: Okay, so from childhood?

Q: Yes. What is the year of your birth?

ZL: 1982.

Q: Are you Shanghainese?

ZL: No, I'm from Jiangsu.

Q: When did you come to Shanghai?

\footnotetext{
${ }^{1}$ ZL's father indicated that he had no time for the interview because he was busy between work and caring for his 90 -year-old father. He believed that ZL's communication ability was good enough for him to be interviewed independently. So his family series only includes interviews with ZL himself and his colleagues, as well as observation of his work.
}

X. Huang $(\varangle)$

Fudan University, 220 Handan Ro, Shanghai, China 200433 
ZL: To Shanghai, I came to Shanghai when I was 7 years old.

Q: Seven years old, with Mom and Dad?

ZL: Yes.

Q: Did your mom and dad come over here for work?

ZL: My parents worked in Shanghai, and they had no time to take care of me. So I was taken back to my grandparents in my hometown.

Q: Oh, you were brought up by your grandparents?

ZL: Yes. Then I was brought back to Shanghai for schooling when I was seven.

Q: Did you go to kindergarten in Jiangsu?

ZL: I went to kindergarten in Puxi, in Minhang District.

Q: Minhang District, so that means you went to kindergarten after you came to Shanghai?

ZL: Yeah.

Q: That's after you turned seven.

ZL: Yes, after I turned 7 years old.

$\mathrm{Q}$ : When did you stay at kindergarten 'til?

ZL: I can't remember that.

Q: Do you still remember when you went to elementary school?

ZL: If I remember correctly it was when I was about 8 years old. ${ }^{2}$

Q: You spent your childhood with your grandparents, so do you remember some impressive stories from your hometown? Something interesting, or sad, or anything.

ZL: My grandparents also took care of me here in Shanghai, and they did very well. However, my grandpa was not used to living in Shanghai, so in the end they went back to their hometown.

Q: Oh, I see. What kind of jobs did your parents do?

ZL: My mom used to do cleaning work and my dad worked as sales rep of a machine packaging business in Puxi, Minhang District.

Q: Oh, your father was a sales re- (before the interviewer had finished, ZL gave the answer in a very eager manner)

ZL: -and my mother did cleaning work.

Q: Do you still have any memories about things that happened in kindergarten?

ZL: No memories, that was a long time ago.

Q: What about your elementary school?

ZL: Little memory about my elementary school, either.

Q: When was it detected that your intelligence might be flawed?

ZL: For that, it seemed to be when I was 10 years old, or 4 , or 5 , or 7 years old? Should be at the age of ten. I used to be good, except for my lisp, good in all aspects, and I was talkative, too.

Q: Okay, you were good in all other aspects, except for the lisp.

ZL: Yes, all good.

Q: This problem was noticed when you were 10 years old, right?

\footnotetext{
${ }^{2}$ ZL cannot remember his age of entry into elementary school, so there's a discrepancy in his answers on this point, but based on his answers, we can roughly conclude that he stayed at kindergarten for 1 year at about seven, and then started elementary school at about eight.
} 
ZL: Yes, but it was already too late due to my parents' negligence, in the end it was too late.

Q: Were you then taken to the hospital for a check-up to find out the cause of your lisp?

ZL: No.

Q: Did your mom and dad take you to treatment for your lisp?

ZL: No. They would take me to see a doctor when I felt sick and uncomfortable.

Q: Just for common illnesses?

ZL: Common illnesses, cough, cold, and so on.

Q: Why didn't your parents take you to treat your lisp then?

ZL: Because it was late, really late.

Q: Have you ever been taken to the hospital to confirm if there was hope of a cure? Or did your parents think it was already too late?

ZL: It was confirmed, too late.

Q: Oh, already confirmed, and the doctor told you it was too late?

ZL: Yes, the doctor said it was too late.

Q: Did you do an IQ test then, in the end, to confirm it was a defect in your intelligence?

ZL: Yes, it was done when I was in junior high school or senior high school, identified in school, and I was given a certificate of disability.

Q: Could you recall if it was in junior high school or senior high school?

ZL: I can't remember, it was a long time ago.

$\mathrm{Q}$ : When your lisp was identified, and some issues were confirmed, how did your parents respond to that? Any big fluctuations in their moods?

ZL: No, because it was too late by the time it was identified.

Q: Did your parents show any sign of sadness?

ZL: No, no.

$\mathrm{Q}$ : Was this condition told to your relatives?

ZL: Our relatives all live in our hometown, and we only go back when something comes up; otherwise, no.

Q: So it was only you and your parents living in Shanghai?

ZL: Yeah. My grandparents also live in our hometown, and they don't come over here.

\section{Excelling at Study and Enjoying Activities at Special School}

Q: Did you get to school yourself or were you taken by your parents?

ZL: My parents took me to school when I was 7 or 8 years old, and then I went to school by myself after I turned eleven.

Q: Would your parents supervise your study? Say, check your homework?

ZL: No, there was no need for that.

Q: Do you remember how long you studied at elementary school? Was it 6 years? 
ZL: Nine years, because ours was a special school, from 1991 to 2003, 2002 or 2003, I don't remember, anyway, a total of 9 years. ${ }^{3}$

Q: You studied at a special school directly?

ZL: Yeah, Lujiazui Special School, and I've never been to a general school.

Q: You went directly to a special school for special children?

ZL: Right.

Q: Just now, you said your lisp was not noted until you were 10 years old, then why were you sent to a special school directly, but not a general elementary school first?

ZL: No, I used to study at a general school, then I was transferred there.

Q: Oh, you were transferred there later.

ZL: Yes, transferred, to that special school.

Q: How long had you been studying in that general elementary school?

ZL: For 2or 3 years, then I couldn't go any further, so I was transferred to the special school.

Q: Oh, so you mean, it's not that you've never been to a general elementary school. You actually studied there for 2or 3 years, and then it was found that you could hardly keep up with the class in that kind of school because of your difficulties in expressing yourself, so you were transferred to the special school, right?

ZL: Right.

Q: During the 2 years at the general elementary school, did you find the lessons too hard for you to keep up?

ZL: No, it was just the lisp.

Q: Did you make any good friends at that time?

ZL: All of us kids played together, and I have very good memories of that.

Q: Did you have any good friends during the 9 years at the special school?

ZL: Yes, some classmates went out for fun together, something like that.

Q: Are you still in touch with them now?

ZL: Not anymore, not after I went to work.

Q: What were the main courses taught at the special school?

ZL: All kinds of courses: Chinese language, mathematics, sports, and cooking, too, you name it. We had classes Monday through Friday, and art class as well.

Q: Compared with general elementary schools, what additional courses were offered to you? You just mentioned cooking. Were there any other courses similar to that?

ZL: Yes, cooking, I completed a cooking course, and I have a cooking certificate. Our school specifically taught us how to cook.

Q: You even have a cooking certificate! You must have learned it very well.

ZL (Hearing compliments, ZL was slightly shy): I might have forgotten what I learned a long time ago - apart from cooking some simple dishes at home, I probably forgot everything about the other dishes.

\footnotetext{
${ }^{3}$ In ZL's answers, what was consistent was 9 years at the special school, so here ZL might be wrong about the exact number of years, or he might have included in the first 2 or 3 years in the general elementary school.
} 
Q: Were there any other special courses in addition to cooking?

ZL: I think there were no more, only cooking.

Q: Did your school organize some activities for you? For example, taking you to shows and things like that?

ZL: No, but we had sports games, and I participated in many sports programs.

Q: What was your favorite course?

ZL: I like both mathematics and PE, and I was good at them. I wasn't good at Chinese language, though.

$\mathrm{Q}:$ You were very active at sports games?

ZL: Yes. By the way, we also had labor skill class. I was very active in those classes, too. I was also active in activity classes. However, the details I've long forgotten, and I haven't been back to the school ever since.

Q: Were there any organized outings in spring and fall?

ZL: Yes there were, in both spring and fall.

Q: Where have you been?

ZL: We've been to Jinjiang Amusement Park three times and Shanghai Zoo several times. There are some other places, but I can't remember. Also, we sometimes went out for fun ourselves.

Q: Did you have any favorite teachers?

ZL: Too many of them: one was our class teacher, and another one was an art teacher. My mathematics teacher was one of my favorites too, according to my memory.

Q: What did the class teacher teach?

ZL: Chinese language. There was also a math teacher and a music teacher, both of whom are very good.

Q: Why did you like them?

ZL: Because they were nice, and their lectures were also very good.

$\mathrm{Q}$ : What were your grades like?

ZL: Well, my grades were below 90, about 80ish.

Q: How did you get along with your classmates? Were you on good terms with them?

ZL: We were like cats and dogs, but on the whole, we got along all right. We were all similar kinds of people.

Q: Oh, the students were mostly similar to you, so easy to get along with?

ZL: Right.

Q: Were the teachers strict with you?

ZL: The teachers were not very strict with us, as long as we studied hard.

\section{Self-reliant, Diligent, and Proactive, Taking Initiatives on the Job Market}

Q: When did you start working?

ZL: Work? You mean here or somewhere else? 
Q: Your first job.

ZL: If I remember correctly, I got my first job in 2004, oh no, it was the job in a factory in 2001.

Q: Was it a fast food restaurant, too?

ZL: No, no, I started working at Papa John's in 2006. I worked in a factory at first, and later I also worked in Carrefour as well as Lotus Supercenter.

Q: What did you do in the factory?

ZL: What the factory produced was mineral water, called Sparkling, ${ }^{4}$ and my job was to deliver water to customers. I can't remember the address of the first factory. It was relocated later, so I don't remember.

Q: So the first job was delivering water?

ZL: Yes, I worked 3 years delivering water, then our factory moved. Since I lived in Pudong, it was inconvenient to go there, so I quit.

Q: What about the jobs after that? How long did you work for them?

ZL: I worked at Carrefour for 2 years, and at Lotus for a year.

$\mathrm{Q}$ : What were your duties at the supermarket?

ZL: Goods handler.

Q: For both supermarkets?

ZL: Yeah, goods handler for both supermarkets.

Q: Did the special school teach you some professional skills?

ZL: No, they didn't, I got the skills myself.

Q: So you started working directly after graduation from the special school, without going to any vocational schools?

ZL: Right.

Q: Was there any period of time when you stayed at home without working?

ZL: No, I don't want to sit idle at home, which is so meaningless. I don't like it.

Q: Did you just look for jobs based on job recruitment information?

ZL: The first job was recommended by the Disabled Persons' Federation, but I got the next two at supermarkets on my own.

Q: How did you find the jobs at the supermarket on your own?

ZL: I went to an employment agency, found the job positions and went for the interviews.

Q: Oh, you went to the employment agency yourself, saw the employment information of the supermarkets, and then you went to the supermarkets for interviews on your own?

ZL: Yes.

Q: Later did you get the job at Papa John's on your own, too?

ZL: It was on my own.

Q: Through which channels did you find it on your own?

${ }^{4} \mathrm{~A}$ drinking water brand. 
ZL: No, no, I got this job myself - I just got it at Papa John's Dongchang Restaurant on my own. I went to the restaurant for the interview, and then started working. I got it on my own. ${ }^{5}$

Q: You went straight to the restaurant?

ZL: Yes, I went to the restaurant.

Q: Then you asked them if they were recruiting employees there?

ZL: Yes.

Q: Have you been working only at this fast food restaurant in Pudong?

ZL: No, no, I first worked in the restaurant on Dongchang Road for 2 years, then worked on Huacheng Road until it was closed in 2015, and then I came here. I was transferred over here.

Q: Which job do you like better?

ZL: Papa John's. Actually, the others weren't bad, either.

Q: All of them were not bad? What are your main duties at Papa John's? Did you have the same duties at all the restaurants?

ZL: Exactly the same, the water bar, delivery, and all other things.

Q: What is the water bar for?

ZL: It's just over there (showing the interviewer by pointing at it), making drinks.

Q: I see. Do you make snacks in the kitchen?

ZL: Yes. Sometimes when we are understaffed, I will go to help out making snacks.

Q: It seems that you worked in many different positions. You would help out wherever hands are needed, right?

ZL: Right.

Q: Was there any professional training when you first came on board at the fast food restaurant?

ZL: Yes, at the first restaurant, I received training about how to make snacks, about the water bar, but not for delivery, since I already knew how to deliver goods.

Q: Do you think the training was too hard? Did you learn fast?

ZL: Not very hard, and I learned pretty fast.

Q: You took the initiative to look for the job, and you weren't urged by your parents?

ZL: Right. My parents would be happy as long as I have work to do. I myself didn't want to stay at home, because it was so boring.

Q: What was your personality like in your childhood, introverted or outgoing?

ZL: I was a very lively person.

Q: Always lively since childhood? Or did you become so after you grew up and started working?

ZL: That's not something I could choose-I was driven to be like that by work.

Q: Does that mean there are changes in your personality?

ZL: Yes, after I started working, I became very open.

Q: Oh, after you started working, you became a more cheerful person?

\footnotetext{
${ }^{5}$ Here ZL might have mistaken "through which channels" for "through personal relationships", so he emphasized repeatedly that he found the job on his own.
} 
ZL: Cheerful, working happily, very cheerful, talking and laughing. I get busy when my colleagues are busy, and when we are not so busy, we make some jokes.

Q: Why were you not so cheerful at school?

ZL: Because I was under the control of my school teachers.

Q: Do you have a pretty good relationship with your colleagues?

ZL: Pretty good, but sometimes we might argue about work.

Q: Argue about what?

ZL: There may be an argument when there's a mistake, not a big argument, though.

Q: Have you ever thought about changing your job?

ZL: No, I don't want to-I've been working here for 6 or 7 years. I can't pretend that I don't love Papa John's. There is a bond, really.

\section{Shy but Longing for Love, Hard to Find Mrs. Right Through Matchmaking}

Q: Have you ever dated a girl?

ZL: Yes, but they were not a good match, too tall.

Q: Are you too tall or are they too tall?

ZL: I am too tall.

Q: Oh, not a good match, but who made the match?

ZL: My mother, or someone from my hometown or my auntie. Anyway, I am too tall.

Q: Oh, so you are too tall. What kind of girlfriend are you looking for?

ZL: No idea.

Q: Do you want to find a girlfriend?

ZL: Yes, of course. But I haven't found anyone suitable.

Q: Not found up until now?

ZL: Right.

Q: Have you ever dated a girl?

ZL: Yes, I dated a couple of girls, but we broke up in the end, and neither of them had jobs, which means I had to support them.

Q: Those girls you dated were all arranged by matchmakers?

ZL: Yes, by matchmakers. Because I had no ... I was a very lively boy, but my mother said I was very introverted and inarticulate.

Q: Okay, according to your mother, you are introverted. And as an introverted person, you don't know how to talk to girls, so girls broke up with you.

ZL: It's possible.

Q: What kind of girls was introduced to you by matchmakers?

ZL: All kinds of girls.

Q: Including girls without disability, who broke up with you later because you weren't suitable for each other?

ZL: Right. 
Q: What are your parents' opinions on your frustration in the pursuit for love?

ZL: They have no opinion.

Q: (Laughing): No opinion?

ZL: It's meaningless thinking about it, and my parents told me to first work hard here and be happy with my work.

Q: You are working hard, aren't you?

ZL: I was delivering takeout orders when you came, and I just came back.

Q: Any possibility you could get lost when you deliver orders?

ZL: What?

Q: Do you know your way all the time?

ZL: Yes, how could I not know my way? When an order is taken, there's always an address, very simple, I never get lost. I know my way very, very well.

$\mathrm{Q}$ : When you deliver the orders to the customers, how do you communicate with them?

ZL: This is very simple, so here is the delivery order, and there's a mobile phone number on it. I would say, "Hello, this is Papa John's delivery, I'm on the first floor, please come down for it." Or I'll press the doorbell and say "hello". The customer will answer, and then I will say, "Miss, this is Papa John's delivery, please open the door."

Q: Okay, sounds good.

ZL: Yes, as easy as ABC.

$\mathrm{Q}$ : When the order is delivered, is it still hot?

ZL: Yes, it is hot-hot and delicious.

Q: Will you tell this to the customers?

ZL: Yes, I will say to them, "Madam or sir or miss, this is your delivery. Please enjoy it while it's hot. Bon appétit!

Q: If you can do a good job, you can always find a girlfriend. What about your classmates and friends? Have any of them found their love or got married?

ZL: I already stopped hanging around with them. Why? Some of them don't work. They would simply come to play with me, but I do not want to hang out with them.

Q: Classmates from which school?

ZL: Elementary school.

Q: Do you have brothers or sisters?

ZL: No, only me.

Q: What are your interests and hobbies?

ZL: Too many of them. I love watching soccer and reading newspapers. I love every aspect of sports. I love watching the World Cup and the America's Cup, as well as the Olympic Games and the Paralympic Games. I watch all sports programs.

Q: You also watched the Paralympics?

ZL: Yes.

Q: Did you take part in Special Olympics in your school?

ZL: No, I didn't.

Q: You work hard and have a wide range of hobbies. I'm sure you'll be able to find your love.

ZL (Sighed): Hey, but reality is reality. 
Translated by Si Zheng

Edited by Andy Boreham and Zijian Chen

\section{The Internet Broadens My World-Interview with Mr. $D^{6}$}

D, male, born in 1987. The only child in the family. Grade IV intellectual disability. Graduated from a special education school - Shanghai Primary Vocational and Technical School. Now working at Shanghai Papa John's.

Interviewee: Mr. D

Interviewer and writer: Xiangmeng Huang

Interview dates: September 25 and October 16, 2016

Interview place: Restaurant where he works.

\section{Lifelong Pity After Falling Down the Stairs}

Q: First of all, please give us a brief introduction about yourself. How old are you this year?

D: I am thirty-one this year, or thirty.

Q: In which year were you born?

D: 1987.

Q: Are you Shanghainese?

D: My hometown is Wuxi, so although my father grew up in Shanghai, my origin is Wuxi.

Q: Did you grow up in Shanghai as well?

D: Yeah.

Q: Are you the only child in your family?

D: Yes.

Q: Your parents know about this interview, right?

D: Yeah, they do.

Q: Why don't they want to be interviewed?

D: They are busy with family matters, so they don't have time.

Q: I'll ask you some questions mainly in chronological order, from your childhood to...

(The interviewer began to cough because of a cold, and D kindly expressed concern).

\footnotetext{
${ }^{6} \mathrm{D}$ 's mother indicated that she had no time for an interview because she was too busy with work. She believed that D's communication ability was good enough for him to be interviewed independently. So his family series includes only interviews with $\mathrm{D}$ and his colleagues, as well as observation of his work. Since D and ZL work in the same restaurant, interviews of their colleagues and observations of their work are combined and are placed after ZL's interview.
} 
D: Drink some water first.

Q: Thank you. Please answer as much as you can remember, just like an everyday chat. You were diagnosed with...

D: No, it happened when a neighbor was babysitting me. At that time, I was a little child just learning to walk, then I fell down from the sixth floor to the fifth floor, rolling down the stairs.

Q: And something was detected after the fall?

D: Yes.

Q: It's not congenital?

D: Not congenital.

Q: How old were you, approximately, at the time?

D: About a year old; anyway, it was when I had just learned to walk.

Q: How did your parents negotiate with the neighbor later?

D: At the time I didn't get checked up. I slept a few hours after the fall, and no problem was noticed at the time.

Q: When did you go to the hospital for a check-up?

D: There were no CT or X-rays in the 1980s, and no one knew about them. I did some physical examinations when I was a child, but everything was normal, except for brain response... poor coordination, but nothing serious.

In the 1990s, when things became more developed, my parents consulted doctors everywhere about my condition, but they all said it was nothing serious. Then we stopped bothering about it. After I went to school, however, they said my IQ was not high.

Q: You have a certificate of disability, right? It is a proof of disability check.

D: No, no, we didn't do the check.

Q: You didn't do the check? Then how could they determine that something is wrong with your intelligence?

D: When I was in elementary school, I did very poorly in my study. I could hardly keep up with my classmates. Because of that, I did an intelligence test, the score of which was very low. Later, when I was in the third grade, I failed in the exam so I was held back a year. After I finished the fifth grade, which was the last year of elementary school study, my mom was concerned that I might go astray in high school, so she sent me to a special school for persons with ID. Since all fifth-graders had to take an intelligence test for enrolment into secondary schools, we got a certificate then.

Q: So the certificate of disability was given by the special school?

D: Yeah.

Q: What are your parents' occupations?

D: My mother is retired now, but still working part time for others; my father is a driver.

Q: What about before, when you were born?

D: The same. My father has always been a driver, and my mother was an accountant before.

Q: Do you know who gave you your name? 
D: My name? Before my sister was born, I was the sixth kid in our family, and the number "six" means "happy", as "six" in Shanghai dialect sounds like "happy", right?

Q: You must be the sixth kid in the extended family, right? Those who were born before you are your cousins, aren't they?

D: Yes, cousins, and "six" sounds similar to "happy" in Shanghai dialect.

Q: How many cousins do you have?

D: If I remember correctly, I have one maternal cousin, one paternal cousin, lots of older female cousins, and two younger female cousins, plus one paternal and one maternal.

Q: Many older female cousins? How many of them?

D: Lots-I'm not sure of the exact number.

Q: Among these relatives, who are you on good terms with?

D: I'm on better terms with my older female cousin.

Q: Do you often drop by her place?

D: I often sing karaoke and go to the movies with my elder female cousins.

\section{Bittersweet Schooling Years}

Q: Who mainly took care of you when you were a young child?

D: It was mainly my auntie, since my parents were pretty busy.

Q: Did you go to kindergarten or just stay at home?

D: I went to the nursery first, and then kindergarten.

Q: How old were you when you went to kindergarten?

D: Normally it would be, you know, about four as a child... I can't remember very clearly, because it was a long time ago.

Q: So you went to kindergarten at the normal age, right?

D: Yeah.

Q: How old were you when you started elementary school?

D: I had a critical disease when I was young, so I probably started elementary school at 8 years old, eight or nine.

Q: What are your impressions of your childhood? For example, was there anything that made you particularly happy or sad?

D: Happy things include going out with classmates singing, playing, and the best memory would have to be hanging out with a bunch of buddies who have been very good friends of mine ever since childhood; the bad moments were basically when my parents beat me.

Q: Why did your parents beat you? For being naughty?

D: For not being serious with my homework - my parents were usually informed by my teachers, or something like that.

Q: You were held back for a year in grade three? 
D: Students like me could join Learning in Regular Classroom (LRC) in those days, ${ }^{7}$ and I hated one of my teachers, because that teacher didn't have a good impression of me.

Q: A teacher of what subject?

D: Mathematics. The relationship between the Chinese language teacher and my parents was also, um, well... (the interviewee did not speak clearly here). Later it turned out not good, so I was held back for a year.

Q: The Chinese language teacher did not have a good relationship with your parents, either?

D: No, their relationship was good, but the math teacher did not agree, because our class was a key class.

Q: At that time the class teacher was that math teacher?

D: No, it was the Chinese language teacher, but the math teacher was the deputy associate class teacher.

Q: He thought you could not keep up with the class, and wanted you to be held back for a year?

D: Yeah.

Q: And your parents communicated with him at the time and then agreed?

D: Right.

Q: What subjects were your favorites, and what subjects were hard for you when you were in elementary school?

D: When I was in elementary school, my math was good but my English wasn't. In the 1990s, I just started English when I was in grade three, so basically I wasn't good at all. I think I was better at science and other subjects.

$\mathrm{Q}:$ A little bit partial to the sciences?

D: No, no, what we learned in our time was different from what you would have learned, it was math and that... I can't remember clearly. Our textbooks were not the same as yours. We had $\mathrm{H}$ version and $\mathrm{S}$ version, ${ }^{8}$ with slightly different content. You can search online for more information. $\mathrm{S}$ version was relatively easier while $\mathrm{H}$ version was more difficult, and at that time we used $\mathrm{H}$ version.

Q: So it was not easy for you to keep up with the class, right?

D: Our class was a key class, and our teachers gave us more homework than others. Sometimes I couldn't turn in my homework, and when our Chinese language teacher learned about that, he gave me a telling-off over it.

$\mathrm{Q}$ : So, the content was difficult to learn, plus the workload was too much?

\footnotetext{
${ }^{7}$ Learning in regular classroom (LRC) refers to a policy of allowing some children with special needs, like those with physical disabilities, mild mental disabilities, amblyopia and hearing impairment and other disabilities, to learn in mainstream classrooms.

${ }^{88}$ In the mid-1980s, the Chinese government allowed the implementation of a "multi-syllabus and multi-course books" or "one syllabus with multi-course books" policy for some disciplines in some regions; that is, either multiple syllabuses or a single syllabus could be adopted, on which basis a variety of course books could be developed. In Shanghai, two series of Chinese language textbooks were published as an endeavor of the curriculum reform. $\mathrm{H}$ version was developed by East China Normal University and the Education Bureau of Xuhui District, while S version was developed by the Shanghai Petrochemical and Education Bureau of Zhabei District.
} 


\section{D: Right.}

Q: When we were young, we had a course called natural sciences. Did you have that course?

D: Yes, I was better at natural sciences.

Q: Oh, so you were better at natural sciences and math?

D: Right.

Q: Then why didn't you have a good relationship with the math teacher?

D: Because the math teacher was more demanding, and I was the second worst student in the class, so he did not want me to drag down such a good class.

Q: Was your elementary school for 5 years?

D: Yeah.

Q: So you were held back for a year and then you continued into your fifth grade?

D: When I was in the fifth grade, I remember we graduated from elementary school in 2000, but I can't remember clearly. After graduating from elementary school, I continued to study at a special school for the students with ID for several years, and then after that we were recommended to a vocational school, where we studied for 4 years and then graduated in 2004.

Q: How long did you study in the special school?

D: I can't remember clearly, a couple of years, probably 3 or 4 years, it must have been 3 or 4 years, I can't remember clearly.

Q: After graduating from the special school, you went to the vocational school, right?

D: Yes.

Q: What were the differences between special schools and general schools?

D: What we learned was very easy, but now I have forgotten everything. Mathematics was very easy. We just learned addition, subtraction, multiplication, division, approximation, and so on, all pretty easy.

Q: What were the other courses offered?

D: Just Chinese language, mathematics and art. There was no English. Pretty much the same as the general schools, but the content of learning was relatively easy.

Q: Was there a course like crafts offered to you?

D: At that time no, but I guess it is offered now. We were among the first ones to go to that school.

Q: What kind of extracurricular activities did you have at the special school?

D: There were classes to develop your skills or hobbies, such as computer, painting, and sports, etc.

Q: Did you choose them yourself?

D: Yeah.

Q: Out of elementary school, special school, and vocational school, which was your favorite?

D: Vocational school, we learned more skills there.

Q: Oh, it made you happy to learn more skills, so what kind of skills did you learn at the vocational school?

D: Baking.

Q: Did you learn any other skills? 
D: As for other skills, well, I also did some reading and writing. There were reading classes at the vocational school, too, but we didn't take them very seriously.

Q: Did you choose to learn baking yourself?

D: We were divided into different classes, such as cooking and baking. I had no idea why I was assigned to that class.

Q: It was a random assignment, not your own choice?

D: Right.

Q: Were there any extracurricular classes in your vocational school?

D: Our vocational school always had confidence in me, so I was given opportunities to take part in many activities. Basically, I was included in almost all activities.

Q: What were the activities that your school took you to?

D: I remember before Special Olympics there was the countdown moment, so the school organized a group of people to go out for that event. Liu Xiang and other celebrities were present, and Han Zheng ${ }^{9}$ came for a meeting. We were told to welcome him and shake hands with him. It was held at Hongqiao Airport, and the whole activity lasted 2 or 3 days, I remember.

Q: You had the opportunity to shake hands with the mayor?

D: Yes. After a period of time, that is, when we were approaching graduation, there was the opening ceremony of a certain exhibition, and I was told to hold the school sign in the front.

Q: Oh, holding the school sign. Did you also participate in any performances?

D: No performances, though.

Q: Did your vocational school organize any other activities, like outings in spring or fall?

D: There were some for sure, but I can't remember those long-past activities very well. We had a spring outing, just for fun, and we did not have many places to go to, so it was either the forest park or somewhere else, just some places like that.

Q: No deep impression?

D: No deep impression.

\section{Social Life and Brotherhood}

Q: I saw some photos of your elementary school classmate reunion in your WeChat ${ }^{10}$ moments.

D: Photos taken at a reunion a long time ago, in the 2000 s.

Q: Is it that long? Are you still in touch with your classmates from elementary school now?

D: Basically yes, because we were a bunch of very good friends, pretty close.

\footnotetext{
${ }^{9}$ The mayor of Shanghai at that time.

${ }^{10}$ WeChat: A popular multi-function social media app in China.
} 
Q: Chatting with you so far, I think your overall condition is relatively good, and your intelligence grade and communication skills are also good. Did you have any difficulties getting along with your classmates simply because of intellectual problems when you were young?

D: No.

Q: Normal social life?

D: Yes, because they had no idea of my condition when we were young. They didn't know until I went to the special school, and we've always been close, like brothers.

Q: So your problem was mainly that you had difficulty with exams and study? No other issues except that? And nothing was noticed in your social life?

D: Right, no one noticed.

Q: When your intelligence test result turned out to be not as high as that of other children, how did your parents respond to that?

D: My parents didn't care. They didn't take it seriously. My parents' concern was that I might go astray in junior high school or senior high school, so I was sent to the special school, and I didn't care much about it. Study at the special school was relatively easy, with not much pressure, so I just followed my parents' decision.

Q: Did they show any sadness or frustration?

D: Nah.

Q: They were both very calm?

D: Yep.

Q: How about your interpersonal relationships with classmates, since childhood...

D: We were like brothers, so the relationship with my friends was pretty good.

Q: Are there any friends you are still in touch with?

D: Yes, there are.

Q: Were you ever been bullied or isolated at school?

D: Yes, I was bullied when I was young, but our class was united like one, and no matter who was bullied, we would come out to fight for him or to settle with a duel, and that's all.

Q: Oh, classmates would help you fight? Were you bullied because of your grade of intelligence? Or was it simply some kids fooling around?

D: Just kids fooling around, like my pencil box being stolen by someone from another class, and boys of our class would go look for him to cause trouble.

\section{Smooth Work After Entering Workforce}

Q: When did you start to work? As soon as you graduated from the vocational school?

D: After graduation from the vocational school, I was assigned to a hotel for an internship, and after about half a year, I was assigned to another hotel for another internship, then I started working there. A year later, I quit the job because of frequent overtime without much pay. 
Q: So you often worked overtime but didn't get much pay?

D: Too tiresome.

Q: Did you get the job at Papa John's yourself?

D: No. After I quit at the hotel, I went to a training center. After being trained for about 2 months, I went to another hotel through referral by my mom's friend. After working there for a while, I came back to the training center, where I found out that Papa John's was recruiting, so I registered, and then an interviewer came to interview us.

Q: So after you went to the training center, you went to work at another hotel through recommendation by your mom's friend?

D: Right. That job was also rather tiresome, so I quit and went back to the center. Just then Papa John's came to interview candidates, I registered, and then they picked me at first sight.

Q: Picked at first sight. That's impressive. What did you do when you worked previously at the hotels?

D: I worked in different departments. In both of the hotels where I worked as an intern, I had the experience of working in the laundry. Later, I was also assigned to the kitchen for butchering.

Q: You were assigned to different departments and then you learned the job requirements along the way?

D: Right.

Q: What job did you like most, in general?

D: I still think it's more comfortable to work in a hotel.

Q: Didn't you say that it was very tiresome just now?

D: Mainly because I was used to hotel work. After I came to Papa John's, I think it is very comfortable working here as well.

Q: So, what are your main duties here?

D: Making snacks, and just now you saw me busy making snacks over there, right?

Q: Yes, I did. Only making snacks? Nothing else?

D: Right.

Q: What are your working hours now?

D: Usually nine to six, sometimes ten to seven.

Q: Basically $8 \mathrm{~h}$.

D: Right. From Monday through Friday. Sometimes when it's busy, I'll be asked to come and help out for half a day on Saturdays and Sundays, for about 3 to $4 \mathrm{~h}$.

Q: Have you worked at any other stores of Papa John's before?

D: Yes, I have. Actually, I was transferred over here from another store, so in total I have been working here for almost... um, more than 2 years roughly.

Q: How long had you worked at the previous store?

D: Half a year there before I came here. I was transferred here because more hands were needed at this store. 
Q: What do you think of the work environment and atmosphere here?

D: For our team here, and "team" is the word we use, cooperation and relationships are all very good.

Q: All very good, and you are all getting along very well with each other?

D: Very well, like brothers.

Q: Are there any recreational activities with colleagues?

D: No, we are always very busy here. Sometimes we have dinner together at night, like a dinner party, but very rarely.

(Then the interviewer coughed again, and D expressed concern one more time)

D: You'd better take some medicine.

Q: Okay, thank you. I'll take some when I go back home.

\section{Strict Parents and Harmonious Family}

Q: Your parents have been strict with you since you were a child, right?

D: Yes, they have, always.

Q: Both Mom and Dad are very strict?

D: Yeah.

Q: When you could not keep up with your study, did your parents show any impatience with your education?

D: No, they are just fine. My parents' temperaments are not bad, though they are strict and demanding.

Q: Would they stay with you or supervise you when you did your homework?

D: Sometimes they would, and sometimes when they were busy, it would be up to me to have self-discipline. If I couldn't control myself, they would stay and supervise me.

Q: They beat you mainly because you didn't behave?

D: Yes. Boys are more mischievous, you know, and girls are relatively quiet. Boys tend to be troublemakers when they are young.

Q: I believe your father and mother are always busy with their work, aren't they?

D: Yes.

Q: Did they often take you out for fun when you were young?

D: My parents were so busy with work that they didn't have much free time, so it was my relatives and friends who would take me out.

Q: Who usually took you out?

D: My auntie and others. Whenever she was free, my auntie would take me to travel, to places nearby, for example Wuzhen.

Q: Generally speaking, what was your personality like when you were young?

D: Very ordinary, nothing special. I think my personality is very common, that's it. 
Q: Are you introverted or outgoing?

D: I don't know.

Q: Do you think that falling down the stairs would have affected your personality in some way?

D: Well, I don't think there's been any major impact as a result of that.

Q: Did you feel any change in your personality when you grew up, shifting from school life to work?

D: Nothing special, I'm still the same person.

Q: When your grade of intelligence turned out a little bit low as shown by the test, did you tell your relatives about that?

D: No, my relatives didn't care, so nothing to tell them about.

Q: Did your parents ever mention this to them?

D: They didn't mention it because nothing was noticeable in me when I was young.

Q: What about now? Do they know it?

D: No, things just remain the same as before.

Q: Oh. There's no need to talk about it specifically because nothing is shown, right?

D: Right.

Q: Have you ever experienced a rebellious period, having constant conflicts with your parents?

D: There was nothing serious about my rebellious period, just refusing to do homework, refusing to listen to my parents, not giving them things when they demanded, coming home late, hanging out with friends and staying very late, things like that.

Q: That was when you studied at the elementary school?

D: It was at the special school. When there were extracurricular activities, I would be back home half an hour late.

Q: Do you now live by yourself or with your parents?

D: With my parents.

Q: Do you keep the money you make or give it to them?

D: I give all the money I make to my parents.

Q: All to your parents, and your parents will give you some pocket money?

D: Sometimes yes, sometimes no.

Q: What if you want to go out to have some fun?

D: I will tell my parents in advance.

Q: What do you usually talk about with your family?

D: Generally, we just talk about what work is like. Nothing in particular. Usually we watch some TV after dinner. That's all.

Q: Do you live far from here?

D: It's okay, not too far. It takes me a little more than half an hour to come here.

Q: You have no difficulty finding your way here, right?

D: Right, no problem. 


\section{Wide Range of Interests Including Internet Surfing}

Q: What do you usually do in addition to work? When I read your WeChat Moments with friends, it seems that you like to go to a variety of exhibitions, to the movies, to CJ, ${ }^{11}$ etc.

D: Because I quite like to hang out with my friends, for instance going to play tabletop games.

Q: What kind of friends do you like to hang out with when you are free?

D: There's a group of tabletop game players online, and they organize activities every Saturday. I go out with them.

Q: Oh, a group of tabletop game players. How did you join this group?

D: I saw it accidentally via a mobile QQ group, and was interested in contacting them.

Q: Do you hang out with your former classmates?

D: Rarely with classmates now, because most classmates from elementary school are already married. We occasionally chat on QQ, but we rarely meet.

Q: What are your hobbies?

D: I have a wide range of interests: tabletop games, anime and comics, movies, listening to music, games, surfing the Internet, watching basketball, hanging out and having dinner with friends, singing karaoke, etc.

Q: What kind of people would comment or like your WeChat Moments?

D: Just a bunch of friends. I don't care about that.

Q: Are they mainly friends and former classmates, or online friends?

D: Friends. Some of them are former classmates, and some are online friends.

Q: In addition to the tabletop game group, have you joined any other groups online?

D: The game group when I played games before, online game group and a group of $\mathrm{YY}^{12}$ friends. We chat every day from morning till night.

$\mathrm{Q}$ : What kind of friends?

D: Friends that I previously came to know through YY, who I would chat and play games with, like Truth or Dare and Tricky Brains, in addition to singing and chatting. I would chat with them until it was time for sleep, because there was nothing to do in the summer vacation.

Q: Summer vacation? That was when you were still in school?

D: When I was in the vocational school.

Q: Are you still playing online games now?

\footnotetext{
${ }^{11}$ Abbreviation of China Digital Entertainment Expo \& Conference (nickname: ChinaJoy), one of the world's most influential digital interactive entertainment events, held in Shanghai in July each year.

${ }^{12} \mathrm{YY}$ Voice was the first software providing voice communication to game teams. It has now developed into integrated instant messaging software with team voice, friend chat, video chat, application games, and other functions.
} 
D: Much less than before. I usually play on Saturday and Sunday, except for the weekends when I end up working. Then I won't play online games, just mobile games.

Q: How easily do you accept new things? For example, how easy is it for you to learn new skills?

D: It's fine. I learn new things fast, and I'm a handyman. It's just that my memory is not so good.

Q: What do you think you are good at doing? And what are you not so good at?

D: I don't know what I'm not good at, and I've never tried to find out.

\section{Longing for Love with Ups and Downs in Reality}

Q: Have you ever dated any girls?

D: I've experienced a lot of romantic frustrations. I met my first love in 2007, and it lasted over 2 months before we broke up. People basically treat me like a person without disability. As long as the girl I like doesn't mind that I am a fat guy, I'll be happy. I'm a dedicated person.

Q: Where was that girlfriend in 2007 from?

D: Shanghai, a high school student, and I was 20 years old then. We met each other online.

Q: Oh, you met online, not through a go-between. You are impressive, able to find a girlfriend online.

D: I might not like a girl who's arranged by a go-between. I've dated about four or five girls, but my parents were not aware of them, because at the time I was still in school. Now I just want to find a girlfriend that I can get married with.

Q: So you met online and you dated offline?

D: Right.

Q: With all of the four or five girls?

D: Yeah.

Q: You met all of them first online?

D: Yep.

Q: How long did the longest one last?

D: Usually less than 2 months, the longest one about 6 months.

Q: What were the reasons for breaking up?

D: I'm a simple-minded person, too simple and too dedicated, just trying to keep her close to me, then she said that she wanted some space, and then we broke up.

Q: Did those girls know which school you were in?

D: They didn't know, and they didn't even ask. I would say that I graduated from a vocational school. Our school offers a technical secondary school diploma-I think I'm no different than other people.

Q: Were those girls high school students or already at work? Or a bit of both?

D: Both. A little while ago I met a girl from our school who's younger than me. I think she's good, and we are dating now. 
Q: You met her online, too?

D: No, she is also a student at the special school. She is a little bit slow, but still like a person without disability—it's not obvious. Besides, she's a nice person.

Q: You are dating now?

D: Yes. I don't want to tell my parents about my romance, because parents are so annoying. They will keep asking me when I'm going to bring her back for them to check her out. I think parents can be summed up in one word: trouble.

Q: Do your parents know about your ex-girlfriends?

D: Why tell them? I just let my female cousins know.

Q: Oh, you only shared the news with your cousins?

D: Yeah. If I tell my parents, they'd just say, "What do you want a girlfriend for? Can you even support yourself with what you're making?" I think they're afraid that someone might take advantage of me or cheat me. They're afraid that I might run into some problems with romance.

Q: Some parents would love to be matchmakers for their children.

D: I don't like that. I don't want my parents to be matchmakers, and I will let them know when we are ready. After all, dedication is the most important thing in love and I don't care that much about appearance, as long as the girl is between 1.50 and $1.60 \mathrm{~m}$ tall and doesn't mind the fact that I'm fat. Her level of education doesn't matter much, either, high school graduate, middle school graduate, it's all okay. What I value is not the outside appearance, but inner beauty. As long as she is an honest person, a person with whom I can live my everyday life with, why bother scrutinizing so much?

Q: So that's why you don't want your mom and dad to do matchmaking for you?

D: Exactly.

Q: Have your mom and dad ever suggested they find someone for you?

D: They have, but I think love is something you make your own decisions in. Well, after having been fooled many times, I don't think too much about love.

Q: Can you explain how you got fooled?

D: I met someone online, then we decided to date offline. When we met in person, however, this someone turned out to be a man. I was so duped.

Q: Oh, you've even run into that kind of thing!

D: Later, we turned out to be good buddies.

Q: (Laughing) Oh, you became good buddies?

D: Yeah.

Q: What about now? Are you still in touch now?

D: Not now. After all, he's someone like me and younger than me. He pretended to be his younger sister when we first chatted online.

Q: He pretended to be his younger sister?

D: Yes. And I didn't know he was a man until we met in person later.

Q: Your experience was quite dramatic.

D: I believe dedication is the most important factor in love. People will come to understand each other anyway. That's why now I think a long-distance relationship is also fine for me. My family is not wealthy. We live in an old house, and I don't 
have enough money. My wage is too low, you know, so girls may not be interested in me.

Q: So you have your own ideas in your quest for love?

D: Yes. Unlike ZL who loves soccer or something, my hobby is computing, sports, online games, and stuff like that. And I usually like to watch NBA.

Q: You are now dating a girlfriend, right?

D: Yes.

Q: Will you go to the movies with her when you are off work?

D: Her parents are strict with her, so we can only date and chat occasionally. I don't want to date too often, as you need money for dating, right? You've got to be very realistic now, have to, you know. Who wants to be with you if you have no money?

Translated by Si Zheng

Edited by Andy Boreham and Zijian Chen

\section{Interview with a Colleague of $\mathrm{D}$ and $\mathrm{ZL}(\mathrm{I})$}

Interviewees: Store manager and kitchen staff

Interviewer and writer: Xiangmeng Huang

Interview date: September 25, 2016

Interview place: Restaurant where they work.

Q: What do D and ZL usually do in the restaurant?

Manager: D mainly makes snacks. From that window (pointing to the window between the kitchen and the dining area) you should be able to see him. ZL is mainly responsible for making drinks at the water bar and delivery. That's why he is not in the restaurant now, because he's out for delivery.

Q: Oh, how's their performance at work?

Manager: Pretty good. Both of them are quite serious with their work.

Q: Would they make any mistakes?

Manager: Occasionally they will, but not many. Everyone is capable of having a subpar performance if they're not careful enough, for instance using the wrong ingredient when they're too busy taking care of too many customers.

Q: Will you criticize them under such circumstances?

Manager: I will point it out to them, and tell them to be more careful next time . I won't give them harsh criticism, just remind them of their mistakes instead.

$\mathrm{Q}$ : What do you think of their personalities?

Manager: I think they are quite happy every day, and will join others if there is a chat. There is no big problem with $\mathrm{D}$, and even if there is, it isn't obvious at all. The only problem with ZL is his lisp, but he has a straightforward and cheerful personality. Both of them are quite good guys and they are almost no different from us. They also work very hard.

Q: Oh, they will chat with others. Do they have frequent social interactions with other colleagues as well? 
Manager: Um, we will chat together when we take a break, but for private interaction, I don't know much about it.

Q: Are they on good terms with others?

Manager: Yes, they get along with others quite well.

Q: Will colleagues ignore them because they have disabilities?

Manager: No no, we all have good relationships with each other.

\section{Interview with a Colleague of D and ZL (II)}

Interviewees: Kitchen staff

Interviewer and writer: Xiangmeng Huang

Interview date: September 25, 2016

Interview place: Restaurant where they work.

Q: How long have you been working here?

Co-worker: For 2 or 3 years.

Q: So you have known D and ZL for quite some time, right?

Co-worker: Right.

Q: Do you usually chat with them?

Co-worker: Yes, chatting, joking, that kind of thing.

Q: What do you usually talk about?

Co-worker: Just small talk about daily life, but I can't remember what exactly. Sometimes, for example, we may chat about a sports match we've just watched.

Q: Do you think they are easy to get along with?

Co-worker: Yeah, they're quite easy to get along with-we're like buddies. Sometimes we would play some jokes and pranks on each other. We are all very happy.

Q: Oh, what do you think of D's and ZL's job performance?

Co-worker: Both are okay. They are quite serious with their work.

Q: Just now ZL said that sometimes there might be an argument over work?

Co-worker: It's not an argument really. It's just that we would talk at a louder volume on things like what ingredients have been missed and that kind of thing.

Q: Will you organize some activities together and take part in them?

Co-worker: We have very few organized activities, almost none.

Q: Will you play mobile games etc. during break time?

Co-worker: Yes, we will. The atmosphere here is quite relaxed and pleasant.

\section{Observation of $\mathrm{D}$ and $\mathrm{ZL}$ at Work}

Observation date: 11:00-16:00, September 25, 2016

Observation place: The restaurant where they work

Observer and writer: Xiangmeng Huang. 


\begin{tabular}{|c|c|c|}
\hline Time & What D and ZL did & Remarks \\
\hline 11:00 & $\begin{array}{l}\text { The observer enters the restaurant; he sits } \\
\text { in the seat facing the window of the } \\
\text { kitchen }\end{array}$ & $\begin{array}{l}\mathrm{ZL} \text { is not in the restaurant at the moment; } \\
\text { he is out doing deliveries }\end{array}$ \\
\hline 11:07 & $\begin{array}{l}\text { D starts to make the pizzas ordered by } \\
\text { customers at the window of the kitchen. } \\
\text { He puts various ingredients of the pizza } \\
\text { on the base, and at the same time takes a } \\
\text { new bag of ingredients from the fridge, } \\
\text { carefully opens it and puts its ingredients } \\
\text { on top of the base }\end{array}$ & $\begin{array}{l}\text { These are routine procedures for making } \\
\text { pizzas }\end{array}$ \\
\hline $11: 10$ & $\begin{array}{l}\text { D completes the pizza, which is then } \\
\text { served by another employee from the } \\
\text { window to the customer }\end{array}$ & $\begin{array}{l}\text { In the process of making pizzas, D looks } \\
\text { up a few times from his work and gently } \\
\text { nods at the observer who's facing the } \\
\text { window }\end{array}$ \\
\hline $11: 19$ & $\begin{array}{l}\text { ZL comes back to the restaurant, walking } \\
\text { rather fast; then he takes new orders from } \\
\text { the manager in the kitchen, helps } \\
\text { colleagues to pack the snacks to be } \\
\text { delivered, nods to the observer and says } \\
\text { "hello" before going out immediately to } \\
\text { deliver again }\end{array}$ & \\
\hline $11: 27$ & $\begin{array}{l}\text { D wipes the tabletop in the kitchen and } \\
\text { sorts out the plates }\end{array}$ & \\
\hline $11: 32$ & $\begin{array}{l}\mathrm{D} \text { takes out a bag of ingredients, opens } \\
\text { the bag and puts the ingredients into the } \\
\text { ingredient box }\end{array}$ & \\
\hline $11: 46$ & $\begin{array}{l}\text { Customers order new snacks, and D } \\
\text { begins to work, the process of which is } \\
\text { basically the same as before }\end{array}$ & $\begin{array}{l}\text { At this point of time, he also makes eye } \\
\text { contact with the observer }\end{array}$ \\
\hline $11: 58$ & $\begin{array}{l}\text { ZL comes back to the restaurant from } \\
\text { delivery, and there are no orders to } \\
\text { deliver, so ZL goes to the water bar and } \\
\text { prepares two drinks for the customers } \\
\text { who have ordered them }\end{array}$ & \\
\hline 12:07 & $\begin{array}{l}\text { D squats down, sorting and cleaning up } \\
\text { the food ingredients beneath the table as } \\
\text { well as the tabletop in the kitchen }\end{array}$ & \\
\hline $12: 19$ & $\begin{array}{l}\text { Before ZL goes out for delivery again, he } \\
\text { passes food ingredients to his colleagues, } \\
\text { helping them finish the unfinished snack } \\
\text { together, and greets the observer again as } \\
\text { he goes out of the restaurant }\end{array}$ & $\begin{array}{l}\text { Communicates with colleagues about } \\
\text { what he needs to do at this point }\end{array}$ \\
\hline $12: 29$ & $\begin{array}{l}\text { D continues cleaning up the tabletop, and } \\
\text { puts the ingredients from the cooler in the } \\
\text { proper place }\end{array}$ & $\begin{array}{l}\text { Because it is the weekend, both store } \\
\text { orders and takeout orders start to drop, } \\
\text { and D's work pace becomes slightly } \\
\text { slower than before }\end{array}$ \\
\hline
\end{tabular}


(continued)

\begin{tabular}{|c|c|c|}
\hline Time & What $\mathrm{D}$ and ZL did & Remarks \\
\hline $12: 42$ & $\begin{array}{l}\mathrm{D} \text {, basically having no work to do, nods } \\
\text { to the observer from the kitchen window }\end{array}$ & \\
\hline $12: 47$ & $\begin{array}{l}\text { ZL comes back to the restaurant from } \\
\text { deliveries }\end{array}$ & \\
\hline 13:00 & Both stand by at their working stations & \\
\hline $13: 15$ & $\begin{array}{l}\text { Start to clean the lid of each ingredient } \\
\text { box at their working stations and put the } \\
\text { lids back onto boxes after washing }\end{array}$ & $\begin{array}{l}\text { At this point, the morning's work is } \\
\text { basically over }\end{array}$ \\
\hline $14: 00$ & $\begin{array}{l}\text { One-hour lunch break starts; they have } \\
\text { lunch, eat fruit, have a rest and check } \\
\text { their mobile phones }\end{array}$ & \\
\hline $15: 00$ & $\begin{array}{l}\text { Lunch break ends and they are } \\
\text { interviewed by us respectively }\end{array}$ & $\begin{array}{l}\text { During the interview, D is eager to invite } \\
\text { the observer to lunch and asks if the } \\
\text { observer wants to drink something; ZL } \\
\text { smokes a cigarette while waiting for his } \\
\text { turn }\end{array}$ \\
\hline 16:00 & End of interview & $\begin{array}{l}\text { There are not many store orders and } \\
\text { takeout orders that day, so the workload } \\
\text { of the two is not heavy }\end{array}$ \\
\hline
\end{tabular}

Translated by Si Zheng

Edited by Andy Boreham and Zijian Che

Open Access This chapter is licensed under the terms of the Creative Commons AttributionNonCommercial-NoDerivatives 4.0 International License (http://creativecommons.org/licenses/bync-nd/4.0/), which permits any noncommercial use, sharing, distribution and reproduction in any medium or format, as long as you give appropriate credit to the original author(s) and the source, provide a link to the Creative Commons license and indicate if you modified the licensed material. You do not have permission under this license to share adapted material derived from this chapter or parts of it.

The images or other third party material in this chapter are included in the chapter's Creative Commons license, unless indicated otherwise in a credit line to the material. If material is not included in the chapter's Creative Commons license and your intended use is not permitted by statutory regulation or exceeds the permitted use, you will need to obtain permission directly from the copyright holder.

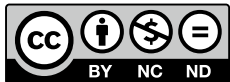

